\title{
A KOGIID SPERM WHALE FROM THE LOWER PLIOCENE OF THE NORTHERN APENNINES (ITALY)
}

\author{
Alberto Collareta $^{1} \oplus$, Franco Cigala Fulgosi ${ }^{2} \&$ Giovanni Bianucci $^{1} \oplus$ \\ ${ }^{1}$ Dipartimento di Scienze della Terra, Università di Pisa, via Santa Maria 53, 56126 Pisa, Italy; alberto.collareta@unipi.it \\ ${ }^{2}$ Strada Martinella 292, 43124 Parma, Italy
}

\author{
KeYwORDS: \\ Adriatic palaeo-area; \\ Mediterranean Basin; \\ Physeteroidea; \\ palaeoecology; \\ psychrosphere.
}

\section{Bullet-Points Abstract}

- We report on a new specimen of Kogiidae from S. Andrea Bagni, a Zanclean fossiliferous site of northern Italy.

- This specimen consists of a partially complete cranium, one vertebra, one fragment of rib, and one tooth.

- The S. Andrea Bagni kogiid is recognized as representative of a new taxon in the subfamily Kogiinae.

- Association of this specimen with teeth of deep-water squaloids provides interesting palaeoecological hints.

\section{INTRODUCTION}

Among modern toothed whales (Cetacea: Odontoceti), dwarf and pygmy sperm whales [Kogia sima (Owen, 1866) and Kogia breviceps (de Blainville, 1838)], respectively) are the only living members of the physeteroid family Kogiidae, known as diminutive and largely unknown relatives of the great sperm whale (Physeter macrocephalus Linnaeus, 1758). Extant kogiids inhabit tropical to temperate open-sea environments outside the Mediterranean Basin (e.g. McAlpine, 2002). The fossil record of Kogiidae is to date represented by a few skulls and more abundant isolated ear bones from Neogene deposits of the Northern Hemisphere (e.g. Barnes, 1973; Pilleri, 1987; Cigala Fulgosi, 1996; Bianucci \& Landini, 1999; Lambert, 2008; Whitmore \& Kaltenbach, 2008; Bianucci et al., 2011; Vélez-Juarbe et al., 2015, 2016), with the significant exception of the late Miocene record from the Pisco Formation of southern Peru (de Muizon, 1988; Collareta et al., 2017).

Here we report on a new fossil kogiid specimen collected by one of us (F.C.F.) at S. Andrea Bagni (Parma Province, Italy), a site where lower Pliocene marine mudstones ("blue clays" sensu lato) are exposed. These sediments have also yielded a rich deep-water elasmobranch assemblage [including teeth attributed to rare squaloid sharks such as Scymnodalatias aff. garricki Kukuev \& Konovalenko, 1988, Scymnodon ringens Barbosa du Bocage \& Brito Capello, 1864, and Zameus squamulosus (Günther, 1877)] which depict the presence of psychrospheric water masses of Atlantic origin in the Adriatic palaeo-area during a phase of remarkable "oceanization" of the Mediterranean Basin (Cigala Fulgosi, 1986; 1996).

\section{Materials AND Methods}

The kogiid specimen from S. Andrea Bagni, which is currently stored at Museo di Storia Naturale dell'Università di Pisa as MSNUP I-17603, consists of a partially complete cranium (lacking the basicranium and the left part of the supracranial basin), one vertebra, one fragment of rib, and one isolated tooth.

\section{Discussions ANd Conclusions}

MSNUP I-17603 belongs to a new taxon of Kogiidae sharing various similarities with the recently described Nanokogia isthmia Vélez-Juarbe et al., 2015, from the upper Miocene of the Chagres Formation of Panama. MSNUP I-17603 mainly differs from $N$. isthmia by displaying two well-distinct fossae on the right side of the supracranial basin (here interpreted as accomodating the vocal chamber and the case for the spermaceti organ, respectively) and a proportionally longer rostrum; it further differs from the late Pliocene Mediterranean species Kogia pusilla (Pilleri, 1987) by the larger size and a different architecture of the supracranial basin. A low temporal fossa and the absence of dental enamel may suggest that, like the dwarf and pygmy sperm whales, MSNUP I-17603 was a suction feeder rather than a raptorial predator; however, the presence of an unusually long rostrum indicates that the foraging technique of this extinct form differed somewhat from that of modern kogiids, which in turn feature the shorter rostrum among extant odontocetes. Our preliminary phylogenetic analysis recovers MSNUP I-17603 as a member of the subfamily Kogiinae, which includes Kogia spp., Koristocetus pescei Collareta et al., 2017, N. isthmia, and Praekogia 
cedronensis Barnes, 1973. Although Koristocetus is recovered as the earliest branching lineage of Kogiinae, the relationships among Kogia Gray, 1846, Nanokogia Vélez-Juarbe et al., 2015, Praekogia Barnes, 1973, and MSNUP I-17603 are unresolved in our strict consensus tree.

Since modern kogiids do not inhabit the Mediterranean Sea, and considering also that they are believed to forage on deep-water cephalopods and fish at or beyond the edge of the continental shelf, the association of MSNUP I-17603 with a psychrospheric elasmobranch assemblage could prove noteworthy. Indeed, at the beginning of the Pliocene, the Gibraltar connection was likely deep and controlled by estuarine dynamics, thus allowing the passage of deep-water organisms (some of which constitute the core of the diet of extant Kogia) from the northern Atlantic Ocean to the Mediterranean Basin (Cigala Fulgosi, 1996, and references therein). More generally, the finding of MSNUP I-17603 suggests that our knowledge of the evolutionary path of kogiid sperm whales is still far from being exhaustive, as well as our understanding of their past diversity, disparity, and distribution.

\section{ACKNOWLEDGEMENTS}

Our gratitude to Chiara Sorbini, Felix G. Marx, Simone Casati, Aldo Marcelo Benites Palomino, and two anonymous reviewers.

\section{REFERENCES}

Barnes L. G. (1973). Praekogia cedrosensis, a new genus and species of fossil pygmy sperm whale from Isla Cedros, Baja California, Mexico. Contributions in Science of the Natural History Museum of Los Angeles County, 247: 1-20.

Bianucci G., Gatt M., Catanzariti R., Sorbi S., Bonavia C. G., Curmi R. \& Varola A. (2011). Systematics, biostratigraphy and evolutionary pattern of the Oligo-Miocene marine mammals from the Maltese Islands. Geobios, 44: 549-585.

Bianucci G. \& Landini W. (1999). Kogia pusilla from the Middle Pliocene of Tuscany (Italy) and a phylogenetic analysis of the family Kogiidae (Odontoceti, Cetacea). Rivista Italiana di Paleontologia e Stratigrafia, 105: 445453.

de Blainville H. M. D. (1838). Sur les cachalots. Annales Francaises et Étrangères d'Anatomie et de Physiologie, 2: 335-337.

Barbosa du Bocage J. V. \& Brito Capello F. (1864). Sur quelques espèces inédites de Squalidae de la tribu Acanthiana Gray, qui fréquentent les côtes du Portugal. Proceedings of the Zoological Society of London, 1864: 260-263

Cigala Fulgosi F. (1986). A Deep Water Elasmobranch Fauna from a Lower Pliocene Outcropping (Northern Italy). In Uyeno T., Arai R., Taniuchi T. \& Matsuura K. (eds.), Indo-Pacific Fish Biology. Proceedings of the Second International Conference on Indo-Pacific Fishes, Ichthyological Society of Japan: 133-139.

Cigala Fulgosi F. (1996). Rare oceanic deep water squaloid sharks from the lower Pliocene of the Northern Apennines (Parma Province, Italy). Bollettino della Società Paleontologica Italiana, 34: 301-322.
Collareta A., Lambert O., de Muizon C., Urbina M. \& Bianucci G. (2017). Koristocetus pescei gen. et sp. nov., a diminutive sperm whale (Cetacea: Odontoceti: Kogiidae) from the late Miocene of Peru. Fossil Record, 20: 259278 .

Gray J. E. (1846). On the British Cetacea. Annals and Magazine of Natural History, Series 1, 17: 82-85.

Günther A. (1877). Preliminary notes on new fishes collected in Japan during the expedition of H.M.S. 'Challenger'. Annals and Magazine of Natural History, Series 4, 20 (119): 433-446

Kukuev E. I. \& Konovalenko I. I. (1988). Two new species of sharks of the genus Scymnodalatias (Dalatiidae) from the North Atlantic and southeastern Pacific oceans. Voprosy Ikhtiologii, 28 (2): 315-319. [In Russian]

Lambert O. (2008). Sperm whales from the Miocene of the North Sea: a re-appraisal. Bulletin de l'Institut Royal des Sciences Naturelles de Belgique, Sciences de la Terre, 78: 277 316 .

Linnaeus C. (1758). Systema Naturae sive Regna Tria Naturae, secundum Classes, Ordines, Genera, Species, cum characteribus, differentiis, synonymis, locis, Tomus I. Editio decima, reformata. Laurentii Salvii, Stockholm, 824 pp.

McAlpine D. (2002). Pygmy and dwarf sperm whales. In Perrin W.F., Würsig B. \& Thewissen J.G.M. (eds.), Encyclopedia of marine mammals, Academic Press: 10071009 .

de Muizon C. (1988). Les Vertébrés de la Formation Pisco (Pérou). Troisième partie: Les Odontocètes (Cetacea, Mammalia) du Miocène. Travaux de l'Institut Français d'Études Andines, 42: 1-244.

Owen R. (1866). On some Indian Cetacea collected by Walter Elliot, Esq. Transactions of the Zoological Society of London, 6: 17-47.

Pilleri G. (1987). The Cetacea of the Italian Pliocene with a descriptive catalogue of the species in the Florence $\mathrm{Mu}$ seum of Paleontology. Brain Anatomy Institute, Bern.

Vélez-Juarbe J., Wood A. R., De Gracia C. \& Hendy A. J. (2015). Evolutionary patterns among living and fossil kogiid sperm whales: evidence from the Neogene of Central America. PLOS ONE, 10: e0123909.

Vélez-Juarbe J., Wood A. R. \& Pimiento C. (2016). Pygmy sperm whales (Odontoceti, Kogiidae) from the Pliocene of Florida and North Carolina. Journal of Vertebrate Paleontology, 36: e1135806.

Whitmore Jr F. C. \& Kaltenbach J. A. (2008). Neogene Cetacea of the Lee Creek Phosphate Mine, North Carolina. Virginia Museum of Natural History Special Publication, 14: 181-269.

Manuscript received 8 July 2018

Received after revision 4 October 2018

Accepted 5 October 2018 